Extended Abstract

\title{
The online production and commodification of gender variant and sexuality diverse young people
}

\author{
Emma Keltie $^{1,} *$, Peter Bansel ${ }^{2}$ \\ ${ }^{1}$ Institute for Culture and Society, University of Western Sydney / Institute for Culture and Society, \\ University of Western Sydney, Parramatta campus, Australia \\ ${ }^{2}$ School and Social Sciences and Psychology, University of Western Sydney / School of Social \\ Sciences and Psychology, University of Western Sydney, Bankstown campus, Australia \\ E-Mails: e.keltie@uws.edu.au; p.bansel@uws.edu.au \\ * Emma Keltie; Tel.: +1- 61296859575
}

Accepted: $8^{\text {th }}$ March 2015

\section{Introduction}

This paper is concerned with the commodification of invisible audience labour by social media platforms such as Facebook. Drawing on findings from focus groups, digital stories and a National Australian on-line survey with gender variant and sexuality diverse young people, we examine the invisible digital labour users/consumers perform when negotiating and choosing identities online. We also consider the material consequences of this labour. In so doing we articulate a number of iterations of digital labour as spaces of enquiry, including:

-Exploring and negotiating digital media and content for a range of purposes, including practices of identity formation or expression;

-Performing unpaid digital labour that has an economic dividend for businesses that capitalize concepts of leisure, freedom, privacy, entertainment and connectedness;

In 2014, Facebook (USA) has expanded the gender options available on the user profile page from three (male, female, blank) to 52 (Facebook, 2013). In reading this as the emergence of a new taxonomy of gendered subjectivity and consumer/subjects generated by the market, we contemplate the interactions with digital/new media technologies young people engage in and the ways in which these technologies facilitate online spaces for the production and consumption of identities. 


\section{Methods (M_Heading1)}

This research draws from quantitative and qualitative data collected in online surveys, digital stories and focus groups with queer young people aged between 14 and 26 in Australia.

This work is framed theoretically by the work of Nikolas Rose. Drawing on the work of Rose (1996) we explore how Facebook provides a space for people to "be their authentic self" - and foreground the extent to which that authenticity is constituted and regulated by the practices through which online identities are created, recognised, expressed, embodied and performed as if originating in or from oneself. How much of who this authentic self has become is bound up in the decisions and choices made when representing oneself online? To what extent is this authenticity a product of the market and consumer choice? Do the categories and practices of identification fix into place a certain type and way of being, for example, trans, gender fluid or cisgendered? For Rose (1996), "human beings have come to understand and relate to themselves as 'psy-chological' beings, to interrogate and narrate themselves in terms of a psy-chological 'inner life' that holds the secrets of identity, which they are to discover and fulfil, which is the standard which the living of an 'authentic' life is to be judged" (p. 22). To what extent, we ask, is the commodification of this invisible identity labour exploitative?

In our analysis we consider the digital labour involved in choosing or recognising oneself as a subject with particular identities, bodies and desires. We pay particular attention to the ways in which social media practices simultaneously open up and commercially exploit possibilities for being and becoming.

\section{Results and Discussion (M_Heading1)}

In thinking through these questions, we draw attention to the invisible user labour that occurs in the formation of identity as an activity that is being repurposed by social media sites, such as Facebook, as an expression of 'individuality' and the 'authentic self' as it creates value that can be exchanged for capital. In this discussion we foreground the extensive amount of time, invisible labour and emotional investment that goes into per/forming oneself as a queer subject. Goran Bolin (2008) argues that within the digital media environment "identity work" is manifesting into "productive labour, contributing to the economics of the production-consumption circuit" (p. 798). As research demonstrates the divide between online and offline practices is blurry, and for many young people their online profiles are becoming an extension of their offline life and part of their identity (Livingstone, 2008). We are interested then, in both the extent to which young people come to know themselves or the truth of themselves online, and in the commodification of this knowledge though which individuality is produced though practices of market segmentation - that is the production of ever more narrowly defined consumers to whom particular goods and services can be targeted. We are concerned with the material effects of this new taxonomy of genders, both in terms of embodied practices of identification and the capitalization and marketisation of queer identities.

Facebook operates on the model that users voluntarily sign up without any economic cost so they can participate, engage and connect with their individual social network. User data is then sold on to advertisers. The commodity logic of social media is a complex exchange of use-value that is realised in the act of not only consumption, but also through acts of production, as user activities create not only content for other consumers, but also the production of user data that is then sold on to advertisers. Andrew Ross (2012) argues that whilst free labour is not new (for example housework, internships and prisons rely on unpaid labour in order for capitalism to function), "untold revenue can be extracted from the steady erosion of the boundary between work and leisure 
time" and for users, digital labour is not experienced as exploitation but is instead constructed as self-discovery, leisure and participation.

Much discussion of the construction of participatory culture emphasises the extent to which audiences are empowered to participate in the production of cultural products (Jenkins, 2006; Burgess, 2006; Burgess \& Green, 2009; Rosen, 2009). Within this context queer youth, as consumers and producers of media texts of identity and life-style, engage in temporally and spatially specific practices of digital labour to produce temporally and spatially specific identities. In this paper, we draw attention to the extent to which conceptualisations of participatory culture, as practices that open spaces for expressing one's own interests within the emerging media ecology, are in tension with possibilities for self-expression in offline spaces. Fischer (2012) in pointing out that Facebook empowers users to contribute 'to their own objectification' (Fisher, 2012, p. 175), signals the extent to which Facebook is a technology for the constitution and regulation of subjects who invent themselves and express their freedom to be/come 'who they really are'. Indeed, our data suggests that queer young people experience and use Facebook and other online platforms as spaces in which they can explore and experiment with their identity.

Figure 1. 52 gender categories available on Facebook.



\section{Conclusions (M_Heading1)}

Audiences are becoming producers of media content and devoting their leisure time to the creation of these products as they operate online. Facebook provides a space for people to explore and experiment with their identity. It is the work young people undertake in identity formation of becoming, or becoming and the intersections with this labour and online practices that we are questioning.

\section{Acknowledgments}

The data we draw on in this presentation comes from a national online survey (conducted in 2012) of 1230 young people aged 17-26 in Australia who identify as gender variant and sexuality diverse. This project was supported by the Young and Well Cooperative Research Centre in Melbourne, Australia (www.youngandwellcrc.org.au). 


\section{References and Notes}

1. Burgess, J.; Green, J. Youtube: Online Video and Participatory Culture. Polity: Cambridge, UK, 2009

2. Facebook. Facebook diversity. Facebook 2013, www.facebook.com/facebookdiversity

3. Fisher, E. How Less Alienation Creates More Exploitation? Audience Labour on Social Network Sites. triple C-Open Access Journal for a Global Sustainable Information Society 2012, 10, 171-183.

4. Jenkins, H. Convergence Culture: Where Old and New Media Collide. New York University Press: New York, USA, 2006

5. Jenkins, H.; Ford, S.; Green, J. Spreadable Media: Creating Value and Meaning In A Networked Culture. New York University Press: New York, USA, 2013

6. Livingstone, S. Taking risky opportunities in youthful content creation: teenagers' use of social networking sites for intimacy, privacy and self-expression. New Media \& Society 2008, $10,393-411$

7. Rose, N.S. Inventing Our Selves : Psychology, Power, And Personhood, $1^{\text {st }}$ ed., Cambridge University Press: Cambridge, UK, 1998

8. Scholz, T. Digital labour: the Internet as playground and factory. Routledge: New York, USA, 2013.

(C) 2015 by the authors; licensee MDPI and ISIS. This abstract is distributed under the terms and conditions of the Creative Commons Attribution license. 